OPEN ACCESS

Edited by:

Shang Gao,

The University of Melbourne, Australia

Reviewed by:

Claudio Martani,

ETH Zürich, Switzerland

Susy Fatena Rostiyanti,

Podomoro University, Indonesia

*Correspondence:

Marina Marinell

m.marinelli@leicester.ac.uk

Specialty section:

This article was submitted to

Bridge Engineering,

a section of the journal

Frontiers in Built Environment

Received: 28 February 2020

Accepted: 30 June 2020

Published: 23 July 2020

Citation:

Antoniou F and Marinelli M (2020)

Proposal for the Promotion of Standardization of Precast Beams

in Highway Concrete Bridges.

Front. Built Environ. 6:119.

doi: 10.3389/fbuil.2020.00119

\section{Proposal for the Promotion of Standardization of Precast Beams in Highway Concrete Bridges}

\author{
Fani Antoniou ${ }^{1}$ and Marina Marinelli ${ }^{*}$ \\ ${ }^{1}$ Department of Environmental Engineering, Faculty of Engineering, International Hellenic University, Thessaloniki, Greece, \\ ${ }^{2}$ School of Engineering, University of Leicester, Leicester, United Kingdom
}

Precast concrete beams for bridges are among the widely used applications of offsite construction with various standardized profiles and lengths being long used in different national contexts. The purpose of this paper is to highlight the important role of standardization in construction and promote the use of prefabrication in the design and construction of highway concrete bridges in countries with low construction industrialization. In this context, this research proposes a set of 45 standard precast extended - I beams, suitable for use in the majority of the common motorway bridge configurations. The selection of the proposed set of standard beams has emerged from data of 109 bridges (2,284 beams in total) constructed along the Egnatia Motorway and two of its perpendicular axes in Greece. Specifically, a database including the dimensions of the precast beams as built [length, depth, upper flange width (UFW), lower flange width (LFW), and web width (WW)], was first created. Following careful data review, 36 different combinations of depth, UFW and LFW and 64 different lengths were detected. This, as well as further data analysis, demonstrated that in the project of Egnatia Motorway no attempt was made to globally standardize the beam configurations; as a result the efficiency benefits typifying standardization were not captured. Therefore, the dataset's variables were subject to thorough statistical analysis, including multi-linear regression and correlation analysis, with the aim to determine a set of standard beam configurations. The resulting set of 45 beams represents 15 different lengths, coupled with three alternative depths each, in compliance to the regulatory requirements for the bridge's effective width. Furthermore, this paper makes specific suggestions for a more effective procurement strategy which will be incorporating award criteria in favor of the use of off-site construction as well as the development of official guidelines enforcing the use of standard design elements. The important role of suitable contracts as well as the provision of training to the main stakeholders involved, are also highlighted. This proposal can help Greece, as well as other countries with nonwell-established relevant standards, launch an effective strategy aimed at harnessing standardization's efficiency benefits in bridge construction.

Keywords: bridge, beam, constructability, DfMA, off-site construction, precast concrete, prefabrication, standardization 


\section{INTRODUCTION}

The construction industry is continually looking for better methods to enhance the value of its infrastructure projects. This requires good design and construction techniques, which provide good value through economy, speed and ease of construction. Although there is no generic production system able to provide maximum value in every occasion, production systems based on prefabrication of components off-site, steadily become more and more competitive and popular (Bjornfot, 2008; CBDG - Concrete Bridge Development Group, 2015). The industrialization of construction has several benefits including higher productivity, waste reduction, time and cost savings, automation, enhanced safety, improved quality and sustainability gains (Gerth et al., 2013; Laing O’Rourke, 2013; RIBA, 2013; Banks et al., 2018).

More bridges are built worldwide using concrete than any other material, because it is widely available, durable and able to provide a high quality and elegant natural appearance. The use of precast concrete components also represents a growing technology with several additional benefits including the achievement of extremely high tolerances at the preparation and positioning of the formwork and the reinforcement, as well as simplified casting, transporting and erection (CBDG - Concrete Bridge Development Group, 2015).

This research aims to promote the use of prefabrication in the design and construction of highway concrete bridges in countries with non-well-established relevant standards, by highlighting the efficiency potential of standardization and by proposing a set of standard precast extended - I beams, suitable for use in the majority of the common motorway bridge configurations. The proposed set of standard beams emerges from data of 109 bridges (2,284 beams in total) constructed along the Egnatia Motorway and two of its perpendicular axes in Greece. Relevant procurement policy recommendations for the development of an efficient regulatory framework aimed at promoting standardization in public works sector are also provided. This research is particularly important for Greece as a series of motorway projects with total length of $350 \mathrm{~km}$ are currently underway. However, as the proposed standard designs have emerged from designs implemented in a great variety of landscapes, their applicability is not restricted in Greece. For instance, they could be very useful to other Balkan countries in light of the current plans for expansion of the trans-European Network in the area.

\section{LITERATURE REVIEW}

This section concerns off-site construction and emphasizes on precast concrete with the aim to highlight practices favoring standardization in design, procurement and construction of concrete operations. Section "Off-Site Construction and DfMA as Standardization Pillars in Construction" briefly discusses off-site construction and explains how the standardization emerging from such a design approach is inextricably linked to DfMA and buildability and their benefits. Section "The Advantages of Standardization in Concrete Operations" presents standardization benefits in the context of concrete operations and Section "International Experience in Concrete Bridge Beams Standardization" focuses specifically on precast concrete bridge beams and the standardization attempts made worldwide to date. Section "International Practices Promoting Standardization in Public Works" completes the section by reviewing regulatory practices applied worldwide with the aim to promote standardization in public works.

\section{Off-Site Construction and DfMA as Standardization Pillars in Construction}

Off-site construction is defined as the manufacture and preassembly of building components, elements, or modules before installation into their final locations (Goodier and Gibb, 2007). Alternative terms to describe the same approach include prefabrication, non-traditional building and industrialized building. The degree of off-site work to be undertaken results in four different levels as follows:

- Component and subassembly: Components are manufactured off-site and then brought together onsite, such as columns, floor slabs and beams (e.g., precast concrete).

- Non-volumetric preassembly: Two-dimensional panelized structures, designed and manufactured in wall and ceiling panels off-site are joined together onsite.

- Volumetric preassembly: Elements of buildings (e.g., plantrooms or bathroom pods) manufactured in a factory are sub-assembled off-site.

- Modular building: Whole segments of the buildings (modules) manufactured three-dimensionally and assembled off-site are fitted together onsite.

Extensive presentation of case studies and applications from each category can be found in Gibb (1999). The biggest advantages of off-site compared with traditional construction are thought to be the decreased construction time on site, increased quality and elimination of defects (Goodier and Gibb, 2007). A systematic presentation of the literature's perceptions on benefits and drawbacks associated with the use of prefabrication in construction has also been given in Goodier et al. (2019). However, according to Lu et al. (2018), although prefabrication has great potential to overweigh conventional construction methods in many aspects, it is not a cure-all solution that automatically promises benefits; it needs due consideration of the wider environment forces, i.e., political, economical, social, and technological factors like, e.g., policies, standards, guidelines, labor, social attitude, resources and site logistics. Furthermore, the early incorporation of off-site production into the design and the supply chain is very important to allow for the realization of potential benefits (Pan et al., 2012), especially in cases of volumetric and modular design (Pan et al., 2008).

The design of prefabricated components or integrated modules generally requires more attention to make these components appropriate for off-site manufacturing and on-site assembly (Lu et al., 2020). In this context, the common thread among the different off-site options is that they incorporate 
a design approach based on the principles of Design for Manufacture and Assembly (DfMA) (UK Parliament, 2018), which is both a design philosophy and a methodology focusing on the ease of manufacture and the efficiency of assembly. DfMA is a well-established approach in sectors such as the automotive and consumer-products industries that are driven by the need to produce large numbers of consistently high-quality products very efficiently (Laing O'Rourke, 2013). Adopting a DfMA approach among others means harnessing design rationalization and standardization. Design rationalization is defined as "the minimization of the number of materials, sizes, components or sub-assemblies," whereas standardization is "a design philosophy requiring the designed product to be produced from those materials, components and sub-assemblies remaining after design rationalization has taken place" (Moore, 1996). Standardization also stands for the use of components, methods or processes enabling regularity and predictability (Gibb, 2001) and specifically relates to the replacement of several components by a single one that can perform all their functions (Perera et al., 1999). Bjornfot (2008) analysis also advocates that value generation is generally facilitated when seen through a standardization lens which allows the engineer to better manage the customer values by developing a design easy to understand and eliminating variation and complexity.

The similarities between off-site construction/prefabrication and manufacturing have pushed DfMA to the fore of the industry's cross-sectoral learning and innovation agenda (Tan et al., 2020). DfMA considers how aspects of the design can be designed in a manner that minimizes works on site and, in particular, in a way that avoids 'construction' (RIBA, 2013). In this context, in the design phase, each component should be checked using the following set of questions: Can the part be combined with another part? Can the function be performed in another way? Can the part be standardized? (Kim et al., 2016). Gibb and Isack (2001) confirm that standardization remains an important part of construction best practice with standardized construction components being associated to lower costs, stable quality and positive learning effects due to process repeatability. Similarly, Edum-Fotwe et al. (2004) note that standardization and the stability it entails are essential for any performance improvement measures to become embedded in operational processes in construction. Gao et al. (2020) holistically examined the construction perspective to the DFMA approach and provided a thorough literature review. A DFMA - inspired approach for construction has also been proposed by Gerth et al. (2013); their 'Design for Construction' (DfC) design evaluation model is based on the number, size, and positioning of components and parts that need to be processed, assembled and handled onsite.

Although the concept of DfMA has only recently become a popular topic in construction, the concept of 'assemblability' has long been considered in the sector through the counterpart concept of buildability (Gao et al., 2020). Buildability refers to 'how the design process can accomplish simple construction' (Rwamamara et al., 2010) and promotes the design rationalization and standardization principles as means to achieve site efficiency, predictability, and better value for money in construction (CIRIA, 1999). The literature further confirms the close relation between design standardization and buildability. For instance, as part of buildability oriented reviews, O'Connor et al. (1987) and Alshawi and Underwood (1996) discussed the negative effect of the variability of element sizes on the complexity of the construction process. Similarly, Fischer and Tatum (1997) identified dimensions and details of elements, e.g., width, length, depth, and type as critical design variables, important for the buildability of structures. Furthermore, in an effort to measure the buildability of designs, the Construction Industry Development Board of Singapore (1995) established the "Buildable Score" of the design, taking into consideration the level of simplicity, standardization, and the extent of the single integrated elements, i.e., combining related components into a single element. Similarly, Martinez et al. (2015), identified the lack of standardized concrete elements in housing construction as a major buildability issue resulting in additional work and inefficiency. Finally, Tegos and Aretoulis (2018), determined buildability as the most important of seven compliance criteria for the design of concrete bridges and included it in the decision support system for the selection of bridge type.

\section{The Advantages of Standardization in Concrete Operations}

In the current competitive construction sector, the main challenge for the builder is the escalating costs of labor and materials while the public demands timely delivery of products with improved quality and durability at affordable prices (Tan et al., 2014). Given that the benefits of offsite construction, i.e., improved quality, lower inventory costs, shorter lead times, less materials waste as well as lower carbon emissions (Gibb and Isack, 2001; Pasquire and Gibb, 2002; Kim et al., 2016; UK Government, 2018b; UK Parliament, 2018), are well known in the industry, standardized precast concrete products are used widely in buildings and infrastructure projects. The manufacturing process encompasses raw material mixing, product casting in molds (or on long casting beds), product curing (using heat and/or steam), storage, product transport and, finally, assembly at a construction site. Typical products include precast blocks, pavers, lintels, tunnel linings, culverts and other structural elements such as slabs and beams (Elhag et al., 2008). A detailed study of the use of innovative technologies in precast industry has been presented by Pan and Pan (2019).

The benefits of standardization offered by precast concrete elements have been well documented in the literature with Oberlender and Peurifoy (2011) noting that design repetition, dimensional standards, and dimensional consistency are critical for the economy of construction. Jarkas (2010) attempted to quantify the impact of the lack of standardization on the construction cost of a precast slab; they concluded that holding the edge-form surface area constant while the ratio of the total number of angles around the perimeter to the total length of the perimeter increases by one unit, the formwork labor productivity decreases on average by $1.33 \mathrm{~m} 2 / \mathrm{mh}$. Similarly, Rwamamara et al. (2010) concluded that the standardization of 
one component of bridge foundation would entail approximately 50 percent lower labor costs for reinforcing the foundations. Burkhart et al. (1987) also support that the design repetition in concrete projects can improve labor output by 40 percent; this entails a significant cost reduction given that labor alone accounts for up to 30 percent of concrete structural frame costs. In this context, as the construction industry is typified by small profit margins, achieving economies of scale is of vital importance. Therefore, standardization of geometry and detail of building components is a crucial factor in this direction, with enormous significance for the success of a project in the construction sector (Tan et al., 2014; Martinez et al., 2015).

The formwork, i.e., the structure that keeps the concrete in place until it gains sufficient strength to support itself, has also been noted as offering opportunities for standardization and industrialization (Shapira, 1999). According to Burkhart et al. (1987), in order for the designer to make formwork more constructible, they should repeat the dimensions of structural members such as beams or columns. This helps workers learn the job fast, increasing output and decreasing labor costs. Also, they should base the design on readily available standard form sizes to avoid the cost of making custom forms. Finally, they should avoid irregularities in the shape of concrete as these decrease productivity and increase cost. In other words, standardization of dimensions, rationalization of design schemes and repetition of element sizes throughout the project are essential to ensure efficient and cost-effective utilization of formwork materials.

Furthermore, since formwork involves a high initial cost, it should be carefully handled and reused as many times as possible (Huang et al., 2004; Jarkas, 2010). As per Martinez et al.'s (2015) experience, when the different dimensions of concrete elements impede the reutilization of formwork panels, their adaptation demands a significant amount of time and resources. Dikmen and Sonmez (2011) further note that standardization enables the most accurate productivity estimation possible which is of crucial importance from the contractor's point of view: an erroneous estimate of the productivities at the tender stage may cause the loss of a bid or on the contrary, may cause getting awarded a contract that will end up with a loss.

Additionally, as Oberlender and Peurifoy (2011) have noted, the advantages of using standard formwork includes not only a higher number of reuses, and thus a reduced overall costs of equipment, but also many more: simpler installation that can be performed even by low-skilled workers, reduced erection time, improved safety for the labor force, better quality concrete surfaces which reduces further finishing work, automation of formwork operations and improved productivity. Along the same lines Tan et al. (2014) highlight the adverse consequences occurring in absence of standardization in concrete operations, i.e., unnecessary expense of additional manpower in customized design and detailing, quick deterioration of the mold leading to shortened production life cycle, increased unit cost, increased storage space requirements and logistic problems.

\section{International Experience in Concrete Bridge Beams Standardization}

Standard precast, pre-tensioned concrete beams have been used for years in many countries, and in various shapes and depths. Standard beams are usually between 1.5 and $3 \mathrm{~m}$ deep and are typically used for spans between 25 and $45 \mathrm{~m}$. The precast beam sizes in these ranges are of manageable size in precasting, transporting, handling and installing operations with readily available machineries (Tan et al., 2014). Some transportation restrictions may apply with beam lengths beyond $30 \mathrm{~m}$, but beams up to $40 \mathrm{~m}$ can generally be accommodated on the road network (CBDG - Concrete Bridge Development Group, 2015). In general, the most economical span /depth ratio is about 20, although they are still viable at a ratio as low as 16.67 (Benaim, 2008).

The literature presents a variety of precast bridge beam standardization attempts in different national contexts (New Zealand, Australia, United Kingdom, North America) with differing section shapes and lengths (Gray et al., 2003; CBDG Concrete Bridge Development Group, 2015; McMullen and Li, 2015). For instance, in New Zealand, a range of precast concrete bridge beams were developed and adopted by the Ministry of Works as industry standards in the mid 1970's. These standard designs included single, double and triple hollow sections, $\mathrm{I}$ beams and $\mathrm{U}$ beams for spans between 6 and $32 \mathrm{~m}$. They were widely used for 20 years leading to time savings and cost efficiency resulting from the use of standard molds (Gray et al., 2003). Furthermore, The Colorado Department of Transport (CDOT) also developed 56 standardized bridge I beams with length between 9.45 and $59.74 \mathrm{~m}$ and depth between 120 and $175 \mathrm{~cm}$ while keeping 3 standard upper flange widths (300, 220 , and $142 \mathrm{~cm}$ ) (McMullen and Li, 2015). Additionally, the American FHWA Standard Plans for Motorway Bridges also provide a choice between 3 standard I beam shapes and two extended-I beam Standard sections with standard dimensions. These sections are applicable to spans from 16 to $36 \mathrm{~m}$ while the provision for structural span to depth ratios to be taken as 18.18 for simple spans and 20 for continuous spans defines the possible span lengths. It is to be noted that according to these standards, designers are expected to consult the Office of Structural Engineering prior to designing a structure with a non-standard shape (Duan et al., 1999). A summary of the variety of shapes, range of length and depth and their names, as originally defined, are shown in Tables 1, 2. Wider shape groups have also been introduced by the authors to facilitate the categorization of the designs. For example the shapes 'Bulb T Beam' and 'Decked BT Girder' have been grouped under the category 'Extended-I beams' to denote that the width of the upper flange is greater than the width of the lower flange.

\section{International Practices Promoting Standardization in Public Works}

Procurement is a critical phase of every construction project which represents the set of strategic decisions made to acquire capital assets and services to meet specified project goals (Tawiah and Russell, 2008) and has enormous impact on the economic prosperity of a region especially in times of recession 
TABLE 1 | Standard beam shapes in different countries (all dimensions in m).

\begin{tabular}{|c|c|c|c|c|c|c|c|c|}
\hline Country & $\begin{array}{l}\text { Shape } \\
\text { category }\end{array}$ & Original shape name & Indicative figure & Span range & Depth range & LFW range & UFW range & References \\
\hline North America & Solid slabs & Solid planks, Deck Slabs & & $0-17$ & $0.25-0.33$ & $1.20-4.60$ & $1.20-4.50$ & $\begin{array}{l}\text { Gray et al., 2003; } \\
\text { McMullen and Li, } \\
2015\end{array}$ \\
\hline $\begin{array}{l}\text { New Zealand, } \\
\text { Australia, North } \\
\text { America }\end{array}$ & $\begin{array}{l}\text { Voided beams } \\
\text { or slabs }\end{array}$ & $\begin{array}{l}\text { Single, double, triple hollow } \\
\text { core beam, voided planks, } \\
\text { double, triple hollow core } \\
\text { planks }\end{array}$ & & $0-20$ & $0.24-0.66$ & $0.50-1.20$ & $0.50-1.22$ & $\begin{array}{l}\text { Duan et al., 1999; } \\
\text { Gray et al., } 2003\end{array}$ \\
\hline $\begin{array}{l}\text { New Zealand/ } \\
\text { Australia/ } \\
\text { North America }\end{array}$ & Box section & $\begin{array}{l}\text { Rect. hollow core beam, } \\
\text { closed flange Super T } \\
\text { beam, Voided box beams, } \\
\text { Single cell box beam, U } \\
\text { Girders }\end{array}$ & & $0-45$ & $0.42-1.90$ & $0.60-1.20$ & $0.60-1.20$ & $\begin{array}{l}\text { Duan et al., 1999; } \\
\text { Gray et al., } 2003\end{array}$ \\
\hline North America & $\begin{array}{l}\text { Extended-I } \\
\text { beam }\end{array}$ & $\begin{array}{l}\text { Bulb T - Beam, Decked BT } \\
\text { Girder }\end{array}$ & $\sqrt{{ }^{-}}$ & $10-60$ & $1.20-1.83$ & $0.64-0.71$ & $1.06-3.00$ & $\begin{array}{l}\text { Duan et al., 1999; } \\
\text { Gray et al., 2003; } \\
\text { McMullen and Li; } \\
2015\end{array}$ \\
\hline
\end{tabular}

TABLE 2 | Standard beam shapes in different countries (all dimensions in m).

\begin{tabular}{|c|c|c|c|c|c|c|c|c|}
\hline Country & $\begin{array}{l}\text { Shape } \\
\text { category }\end{array}$ & Original shape name & Indicative figure & Span range & Depth range & LFW range & UFW Range & References \\
\hline $\begin{array}{l}\text { New Zealand, } \\
\text { Australia, North } \\
\text { America }\end{array}$ & I beam & I girder & & $0-50$ & $0.46-2.10$ & $0.20-1.00$ & $0.20-1.00$ & $\begin{array}{l}\text { Duan et al., 1999; Gray } \\
\text { et al., } 2003\end{array}$ \\
\hline United Kingdom & $\begin{array}{l}\text { Inverted T } \\
\text { beam }\end{array}$ & $\begin{array}{l}\text { TY beam, Inverted T } \\
\text { beam, Y beam, SY } \\
\text { beam. M beam }\end{array}$ & & $0-40$ & $0.35-2.00$ & $0.50-0.77$ & & Gray et al., 2003 \\
\hline $\begin{array}{l}\text { New Zealand, } \\
\text { Australia, } \\
\text { United Kingdom }\end{array}$ & U beam & $\begin{array}{l}\text { U beam, Close flange } \\
\text { Super T beam, Super T } \\
\text { and the Tee-Roff beam }\end{array}$ & & $0-35$ & $0.75-1.80$ & $0.50-0.90$ & & Gray et al., 2003 \\
\hline North America & $\begin{array}{l}\text { Inverted U } \\
\text { beam }\end{array}$ & Inverted U Section & & $15-30$ & 1.35 & & 1.65 & Gray et al., 2003 \\
\hline North America & Ribbed & $\begin{array}{l}\text { Double Tee, Triple Tee, } \\
\text { Decked Next Girder }\end{array}$ & U_ & $0-37$ & $0.65-1.05$ & & $1.20-1.83$ & $\begin{array}{l}\text { Gray et al., 2003; } \\
\text { McMullen and Li, } 2015\end{array}$ \\
\hline
\end{tabular}

(Antoniou et al., 2016b). Procurement can also potentially play a critical role in the adoption of off-site manufacturing technologies at the subsequent implementation stage. Especially in the context of public works and infrastructure, governments, as the largest single clients of the sector, are well in the position to actively promote and facilitate off-site construction uptake through relevant national procurement rules (UK Government, 2018b). Lu et al. (2018) are also of the opinion that the governments tend to stipulate a high level of prefabrication as part of their ambitious construction plans and highlight this practice as similar to a prefabrication "race." Pan and Goodier (2012) further note that government-funded social housing has traditionally been the main driver for off-site technologies.

Such an example of a national government striving to aggregate and stabilize demand for off-site construction by putting its own projects at the forefront, is the United Kingdom government. The use of off-site construction methods is not new to the United Kingdom, as in various historic occasions they have been massively used to address various needs (e.g., emergency housing after WWII) and ameliorate the construction industry's poor performance (Nadim and Goulding, 2009; Taylor, 2010). Currently, off-site construction lies at the core of an ongoing governmental initiative called 'Construction Sector Deal,' aiming to transform the productivity of the sector through the promotion of standardization. In this context, since November 2017 there is a "presumption in favor" of off-site construction across suitable capital programs, where it represents best value for money. The presumption in favor binds five Governmental Departments (the Department for Transport, the Department of Health and Social Care, the Department for Education, the Ministry of Justice and the Ministry of Defence) to include at least one off-site manufacture-based option at the development stage of their projects (UK Government, 2018b).

Furthermore, the UK Government is also actively promoting standardization and buildability through the adoption of a 'Platform Approach to DfMA' which minimizes the need to design bespoke components for different types of assets. Specifically, this proposal suggests that the design, procurement and construction of built assets for the above five departments use a defined set of standardized and interoperable components. 
This approach will enable digitally designed components to be used whenever possible, not only across different types of built assets, but also across different sectors. For example, a single component could be used as part of a school, hospital, prison building or station. The Department for Transport and associated delivery bodies (e.g., Transport for London, Highways England) are also expected to use this approach and they have also been encouraged to look to the roll out of automated design for components that are unique to transport infrastructure (UK Government, 2018b). The UK Government also strongly recognizes that designers, contractors and suppliers must all have early involvement in a project for off-site manufacture to be successful. This requires a change in business models in the sector and amongst clients, both private and public sector, as well as far greater collaboration (UK Parliament, 2018). Furthermore, the Government acknowledges the need to establish and promote standards for components manufactured off-site and the associated manufacturing techniques as this will strengthen customer confidence in the quality, safety and future performance of the assets produced (UK Government, 2018a). The above is completely in line with Mao et al.'s (2015) and Lu et al.'s (2018) view that political factors like governmental regulations and incentives are among the strongest enablers or barriers to prefabrication adoption in a certain context.

Besides the United Kingdom, Singapore is also a country where DfMA has been officially recognized by the Government as a means to help contractors change the way they build and to sustain productivity improvements. As per Gao et al. (2018), the adoption of DfMA was mandated in 2014 as one of the conditions for developments on Government land sites. As a result, the Building and Construction Authority has to give notice of upcoming projects requiring higher levels of prefabrication so as give construction firms ample time and runway to plan ahead on how best to deploy resources. Furthermore, as a regulatory body, the Singapore government has activated a DfMA-relevant legislative framework which introduces the Minimum Buildable Design Score (B-score) and the Minimum Constructability Score (C-score), which both seek to encourage the adaptation of offsite and efficient techniques during the construction phase. Furthermore, Singapore has witnessed encouraging results in promoting prefabrication through financial incentives (such as interest-free financing) (Park et al., 2011). Lu et al. (2018) confirm that a policy foreseeing financial incentives if a project has achieved certain requirements in using prefabrication can effectively encourage its adoption.

\section{Main Points From the Literature Review}

The previously presented literature review clearly demonstrates the important role of prefabrication or off-site construction toward the improvement of construction operation's efficiency through standardization, DfMA and increased buildability. Design repetition, dimensional standards and dimensional consistency are critical for the economy of construction as well as for the achievement of stable quality and higher productivity. In this context, concrete operations can particularly benefit from the implementation of manufacturing practices to produce standardized elements such as blocks, pavers, lintels, tunnel linings, culverts and other structural elements such as slabs and beams (precast concrete). Standard precast, pre-tensioned concrete beams have also been used for years in the construction of bridges in many countries, and in various shapes and depths. The adoption of prefabrication in public works and infrastructure can actively be promoted by governments, as they are in the position to impose relevant national procurement rules as well as create demand for prefabricated components through appropriate infrastructure planning. Examples of countries where relevant official initiatives to facilitate offsite construction have been undertaken, is the United Kingdom and Singapore.

\section{METHODOLOGY}

The current paper constitutes a case of "applied" research or "action research," i.e., research which involves the researcher suggesting solutions to particular problems (Fellows and Liu, 2008) and is distinguishable in terms of its purpose, which is primarily the improvement of a practice of some kind (Robson and McCartan, 2016). Action research is more common in fields such as business and management and can involve the collection of both quantitative and qualitative data for the formulation of the diagnosis of a problem and in the emergence of a solution (Bryman, 2012).

Liu (1997) notes that action research is a process different from a hypothetical-deductive type of research; it is highly context dependent and so, is neither standardized nor permanent, as it is reliant on the project and the knowledge of the persons involved. Furthermore, in action research, the researchers collaborate with practitioners and other stakeholders with the aim to produce knowledge and enact change (O'Leary, 2004). Given the rapidly changing nature of organizational settings and the continuing pressure on organizational members to improve their performance, it is likely that action research has a considerable contribution to make in the management of change (Jupp, 2006).

According to Koshy (2005), the unique features of action research can be described by the following keywords: better understanding, improvement, reform, problem-solving, stepby-step process and modification. Furthermore, Jupp (2006) highlights the fact that its outcomes are not necessarily 'findings' in the conventional sense of theoretical progress, but in terms of new practices, changed behavior patterns or improvements in organizational processes.

A widely adopted version of action research views it as a spiral, or cyclical, process which starts with defining the enquiry and describing the situation and continues with collecting and analyzing data. Data analysis enables the researcher to identify discrepancies between the desired and the actual state, and form the basis for the introduction of changes that will tackle the gap. The circular process gets completed with the implementation and evaluation of the change and final decision on future action (Robson and McCartan, 2016).

The current research aims to introduce an efficient standardization proposal for precast concrete bridge beams. The project of Egnatia Motorway which is the longest recently constructed motorway in Greece (around 1,000 km including 
perpendicular connecting axes), was selected for the collection of data. Gaining the required access to the designs of the project was greatly facilitated by the fact that one of the authors has 22-year professional experience, 14 of which as a Project Manager, within 'Egnatia Odos S.A.', the public owned client organization responsible for the design, construction operation and maintenance of the Egnatia Motorway. Therefore their network included suitable contacts which were properly utilized. The critical role of personal contacts in effective research conduct has also been noted by Taylor et al. (2016). This data collection approach is alternative to interviewing, or asking someone to fill in a questionnaire for the purposes of the research, and belongs to a group of methods known variously as unobtrusive measures or indirect observation (Robson and McCartan, 2016).

Data collection started with the authors gaining access to the database including information for all the 919 concrete bridges designed and constructed along the Egnatia Motorway and two of its vertical axes (also 4-lane bi-directional motorways). All the bridges were built between 1998 and 2015 according to the same design specifications, i.e., the German codes DIN 4227, DIN 1045, DIN 1055, DIN 1072, DIN 4014, the Greek Reinforced Concrete Code (2000) and Earthquake Design Code (2000), as well as Eurocode 8 . Since the research focus was on standardization, the authors decided to isolate the data concerning 109 concrete bridges with precast beams. The separate dataset which was formulated included information for the total bridge length, the bridge width, the number of spans, the number of beams per span, shape, length, and depth of the beams, the design office responsible for the design and the contractor responsible for the construction. The information from this dataset helped the authors to locate the final design documents for each of the 109 bridges and create a new database including information for the shape and dimensions of the respective precast beams, as built. A total of 2,980 precast beams of varying lengths, depths and cross-sectional shapes was identified and statistically processed. Given that $77 \%$ of the beams (2,284 beams) were of the ExtendedI beam cross-section (other categories observed were I beams, $\mathrm{T}$ beams and Inverted $\mathrm{T}$ beams), the analysis and standardization proposal was restricted to this shape.

Next, a thorough statistical analysis was undertaken by the authors to establish the lack of standardization in design, and highlight the need for the development of an effective regulatory framework, including standardized elements. In this context, the next step included the selection of a set of Extended I beams as proposed standardized elements. These emerged following careful review of the dataset's descriptive statistics and application of multi-linear regression and correlation analysis between the major beam cross-sectional dimensions (depth, upper flange lower flange and web width). This set of standard beams is able to accommodate the majority of motorway bridge configurations and is applicable not only in highway projects in Greece but also in the wider Balkan area where the transEuropean Network is currently planned to expand. This step fulfills the primary purpose of action research which is the identification of discrepancies between the desired and the actual state and introduction of changes which will result in the improvement of a practice.

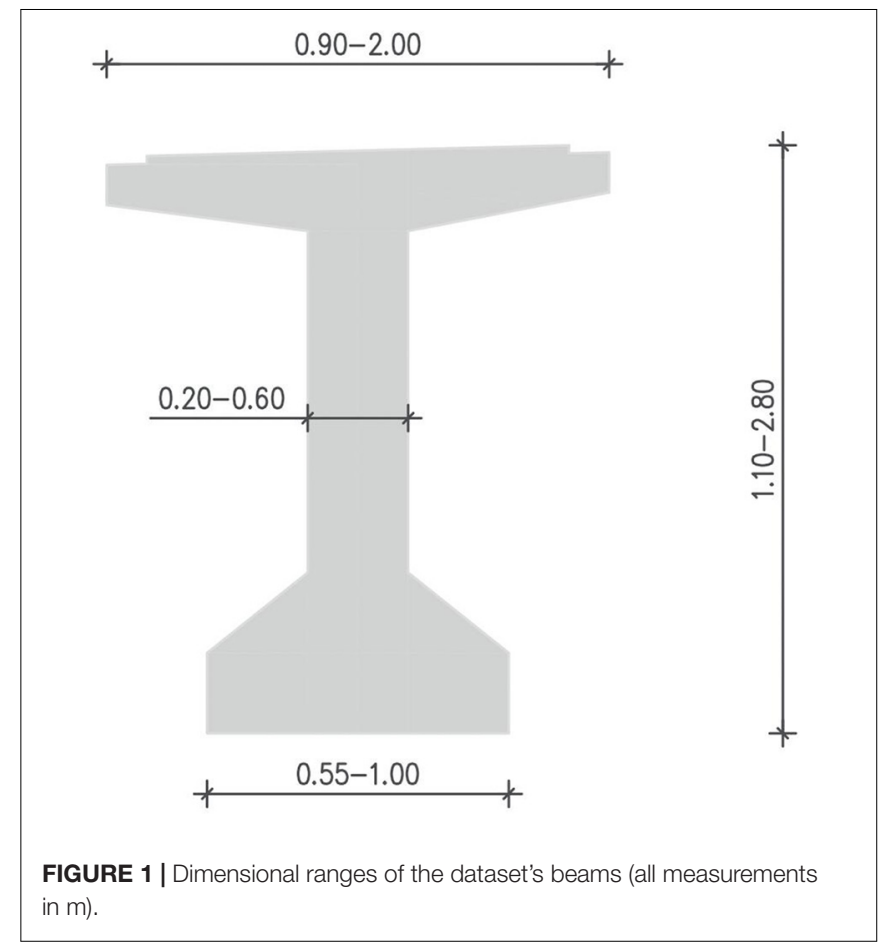

\section{DATA ANALYSIS}

\section{Assessment of Standardization Level in the Dataset}

Upon analysis, it was found that the precast Extended-I beam lengths of the dataset include 64 different beam lengths ranging from 13.05 to $44.30 \mathrm{~m}$, while the depth of the beams take 18 different values ranging from 1.10 to $2.8 \mathrm{~m}$. Regarding upper flange width (UFW), lower flange width (LFW), and web width (WW), the dataset includes 15 different UFW values ranging from 0.90 to $2.0 \mathrm{~m}, 10$ different LFW values ranging from 0.50 to $1.00 \mathrm{~m}$ and finally 6 different $\mathrm{WW}$ values ranging from 0.20 to $0.60 \mathrm{~m}$ (Figure 1). From the frequency analysis it was also found that the most common UFW values are 1.40 and $1.50 \mathrm{~m}(48 \%$ of the beams), the most common LFW values are 0.75 and 0.80 $(57.7 \%)$ and the most common WW is $0.25 \mathrm{~m}$ (69.9\%).

Additionally, following careful review of the 2,284 beams, 70 alternative configurations were identified resulting from 36 different combinations of depth, UFW and LFW and 64 different lengths. Figure 2 shows the various lengths encountered for each of the 36 alternative Extended - I sections while Figure 3 shows for each of the 36 sections the total number of beams constructed. The different shades of black and gray correspond to the different lengths. For instance, section number 30 is the most popular one with a total of 295 beams constructed in 10 groups of different lengths and varying quantities.

It can be observed from Figure 2 that the vast majority of the beam configurations (59 out of 70 or $84.2 \%$ ) correspond to lengths greater than $27 \mathrm{~m}$ (shaded zone), while it is also evident that most of the sections ( 23 out of 36 or $64 \%$ ) are associated with one specific length only. There are however 8 sections which can 


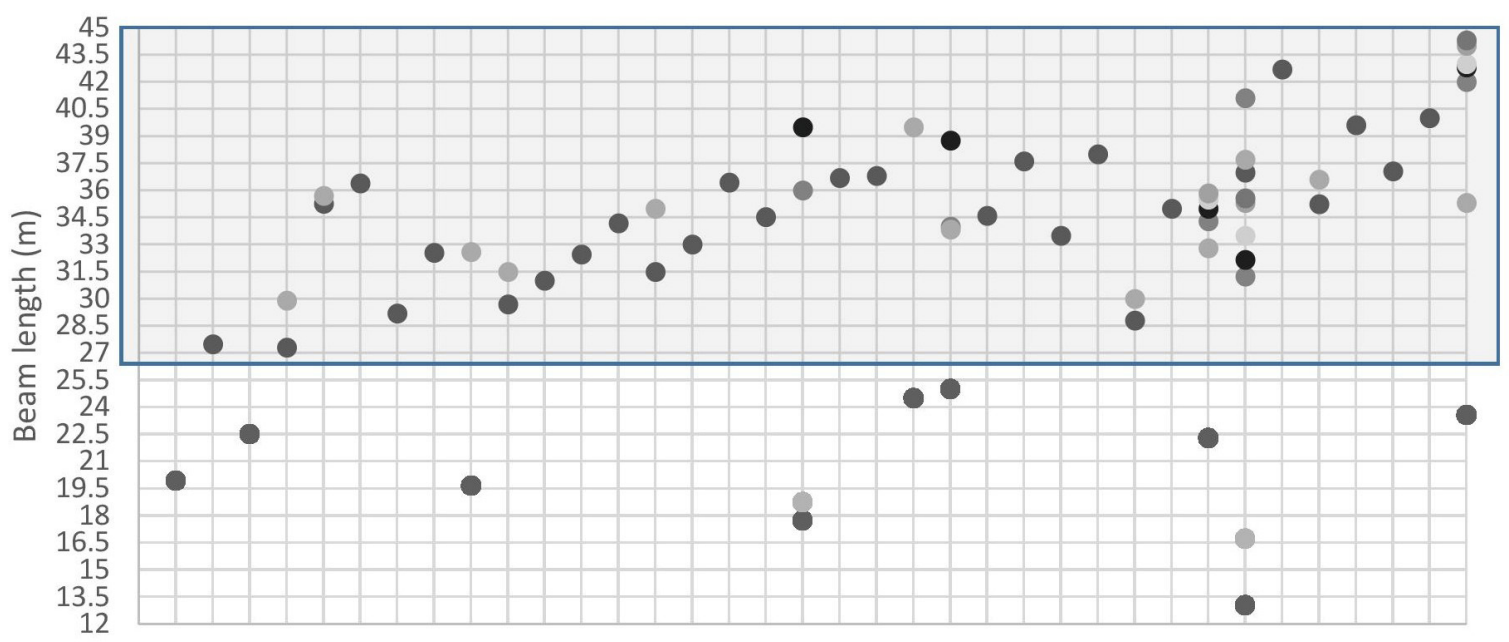

$0 \begin{array}{lllllllllll}0 & 2 & 3 & 4 & 5 & 6 & 7 & 8 & 9 & 1011 & 12131415161718192021222324252627282930313233343536\end{array}$

Alternative Extended-I beam sections

FIGURE 2 | Beam lengths per section.

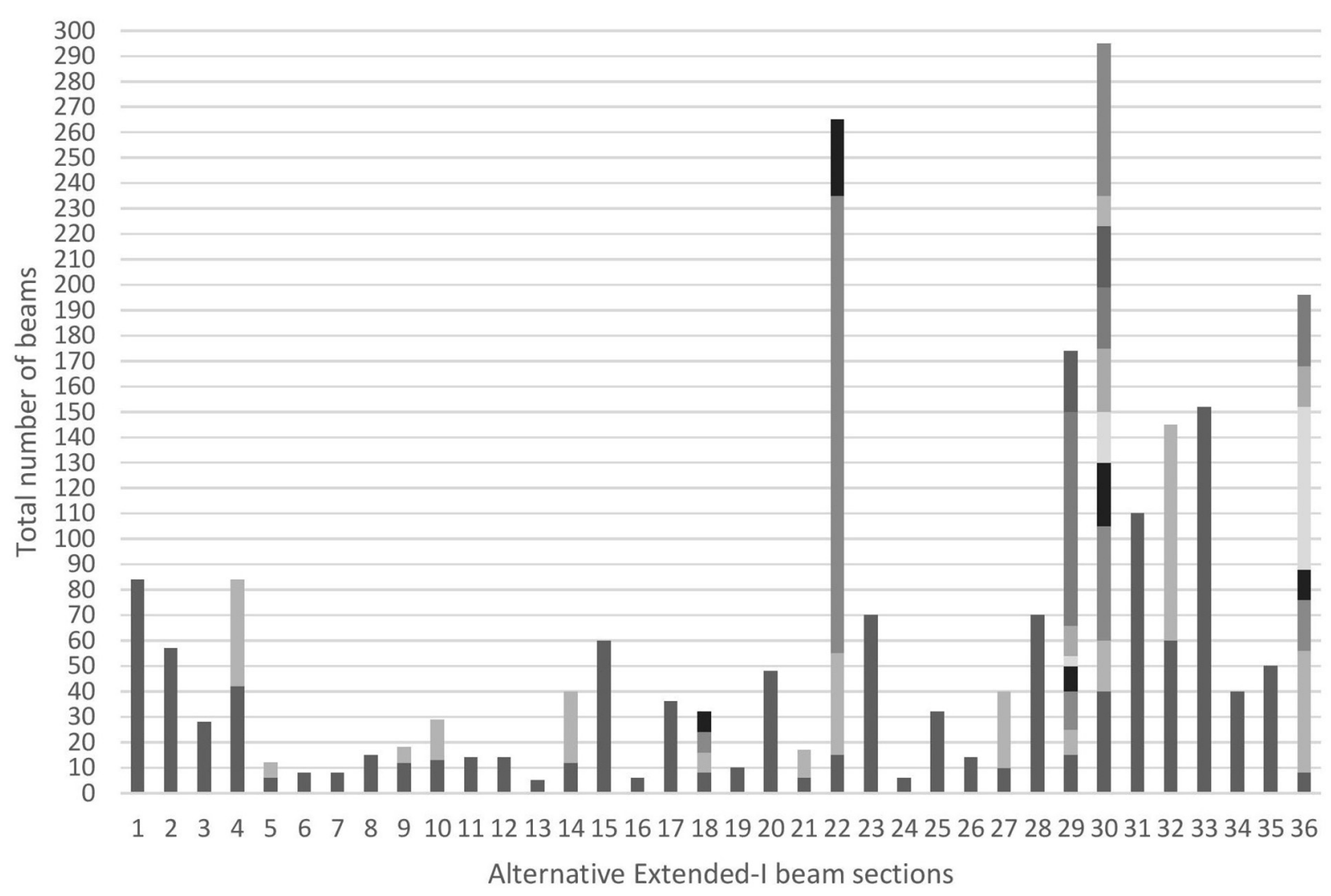

FIGURE 3 | Total beams constructed per section.

be found in beams of two different lengths, another 2 sections (number 18 and number 22) which can be found in beams of four different lengths, section number 29 , which is found in beams of six different lengths, section number 36 , which is found in beams of seven different lengths and finally section number 30 , which is associated with 10 different lengths. A closer look at the alternative lengths associated with each of the sections (Figure 2) reveals that in many cases (e.g., sections number 5, 18, 


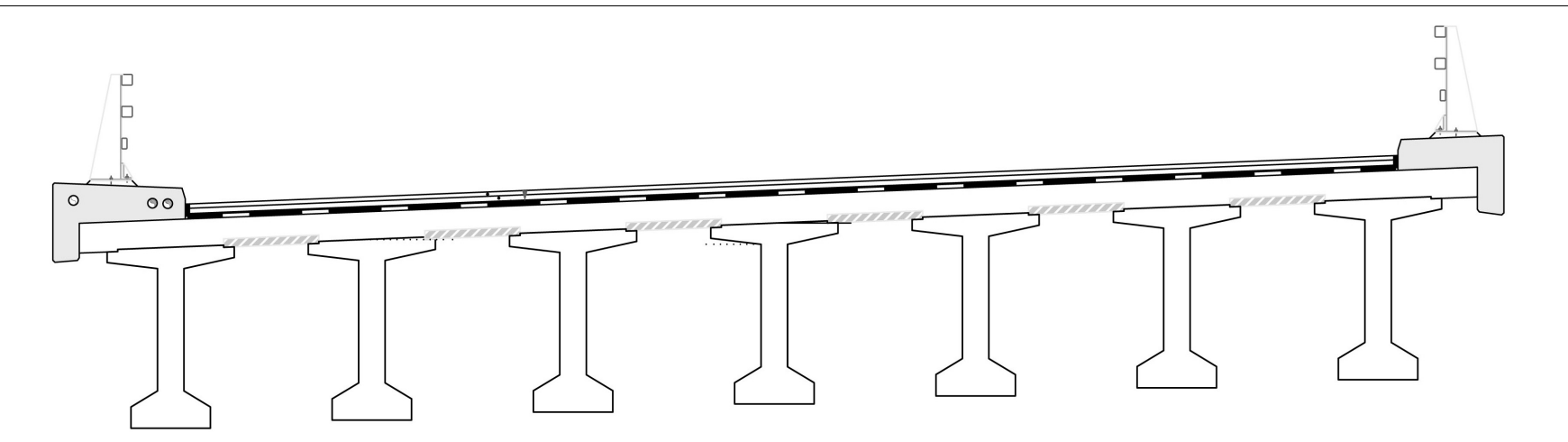

FIGURE 4 | Typical precast beam bridge cross section arrangement.

$22,29,30,32,36)$ the difference in lengths is less than one meter, occasionally much less than this.

Further data analysis reveals that Section 22 is found in two groups of beams designed by the same consultant, one with 40 and one with 180 beams, which have a length difference of $15 \mathrm{~cm}$ only. Similarly, section number 30 is associated with one group of 20 beams and a second group of 60 beams which only differ by $26 \mathrm{~cm}$. The same section is also used in two groups of 45 and 40 slightly longer beams that have a length difference of $0.7 \mathrm{~m}$ only. Similarly, in section number 29, 84 beams were designed at a length of $35.50 \mathrm{~m}$ and at the same time another 38 were also designed at three additional very similar lengths $(34.30,35.00,35.84 \mathrm{~m})$. Very similar is also the case of section number 36 where in the interval between 42 and $44.3 \mathrm{~m}, 5$ different beam lengths have been selected by the same design consultant.

Figure 3 also shows that 13 out of 36 sections (36\%) have been used in less than 20 beams of differing lengths in total, while the majority of the more frequently used sections present very high length variability, which results in many subgroups of much fewer identical beams (same section and same length). For instance, section 30 is found in 295 beams in total, but since there are 10 different lengths involved, the biggest subgroup counts no more than 60 beams while the smallest counts just 12 . Among the 70 different configurations encountered, the largest group of identical beams is a group of 180 beams (section number 22 , length $34.00 \mathrm{~m}$ ) which is less than $8 \%$ of the 2,284 beams of the dataset.

As a result of the above, it can be safely concluded that in the project of Egnatia Motorway no attempt was made to standardize the beams' configurations so as to facilitate their construction on a project level. Furthermore, similar conclusion can be drawn after taking into account how the precast bridges were tendered for construction in 31 different contracts; it is worth noting that 20 of the contracts required the construction of at least 2 different configurations with 5 of them encompassing more than 4 . There is no doubt that had proper design guidelines toward standardization been implemented, the aforementioned variation would have been drastically reduced and much higher efficiency levels could have been achieved in both design and construction.

\section{Rationale for the Determination of Standardized Precast Beams}

This section presents the rationale for the determination of a set of different standard beams which along with other policy recommendations, detailed in Section 5, constitute this research's contribution toward the promotion of standardization in concrete bridge construction.

\section{Typical Arrangements in Precast Concrete Bridge Construction}

The standard practice implemented by Greek contractors is the construction of the bridge deck in two phases. Phase 1 encompasses the construction in factory conditions of the precast beams and the application of pretensioning. The constant width panels, which connect the beams and are used as permanent formwork for the in situ casting of the deck slab, are also constructed in the factory in phase 1 . In phase 2 , the precast beams and panels are placed in position using crawlers or cranes, the deck reinforcement is laid, and then, the slab above the beams, as well as the continuity slab and the cross beams are cast in situ. Figure 4 shows a typical precast beam bridge cross section and Figure 5 shows the arrangement for the continuity slab at the pier head in the longitudinal direction.

\section{Length of Proposed Standard Beams}

In order to define a reasonable multitude of standardized lengths for the Extended -I beams, the 2,284 beams of the dataset were reviewed. Given that $85 \%$ of all the beam lengths were found within the range between 22 and $43 \mathrm{~m}$, it was decided that the standard elements would represent this range, at intervals of $1.5 \mathrm{~m}$, i.e., 15 alternative lengths. The decision to standardize at $1.5 \mathrm{~m}$ intervals is a result of the observation that in most bridge designs available, the pier head width used for the placement of beams in the longitudinal direction is around $3.9 \mathrm{~m}$. Also, a typical distance from the edge of the pier to the bearing is $0.25 \mathrm{~m}$, a minimum bearing diameter is $0.50 \mathrm{~m}$, a typical distance from the bearing to the edge of the beam is $0.20 \mathrm{~m}$ and the minimum space between consecutive beams required on either side of the pier's center line for inspection purposes is $0.35 \mathrm{~m}$. This means that assuming a slightly larger pier head width of $4.10 \mathrm{~m}$, a space of 2.05-0.25-0.50-0.20-0.35 $=0.75 \mathrm{~m}$ remains available on each 


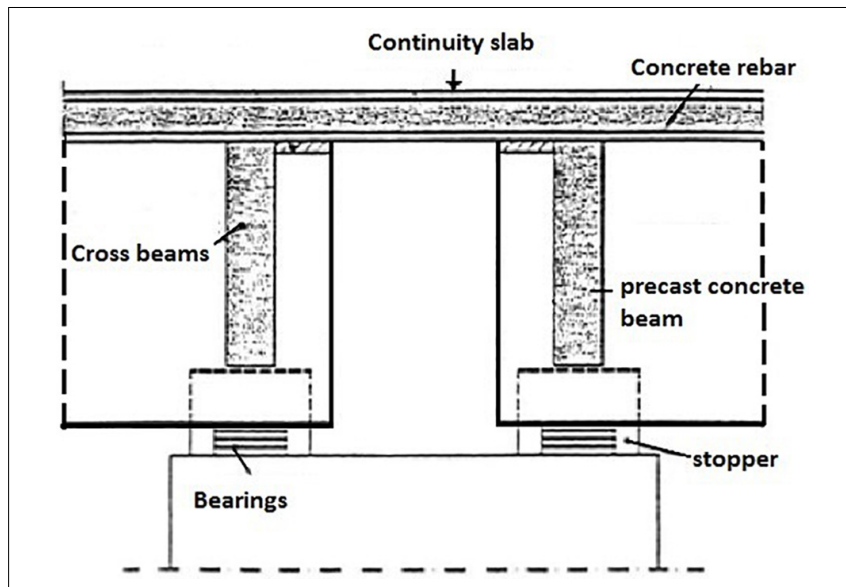

FIGURE 5 | Typical arrangement for the continuity slab at the pier head (adapted from Greek Ministry guidelines).

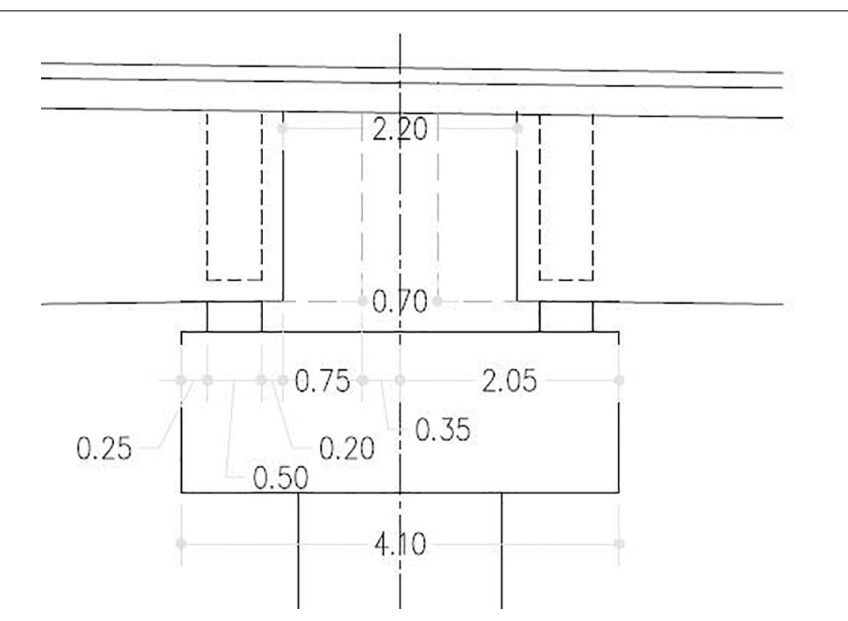

FIGURE 6 | Schematic representation of typical consecutive beams positioning (dimensions in $\mathrm{m}$ ).

side of the pier's center (Figure 6). As a result, the minimum length of each beam is up to $1.5 \mathrm{~m}$ shorter than the pier center to -pier center distance. For the beams of the first/last span of the bridge, the position of the abutments can be adjusted accordingly if required, by relocating them by $0.75 \mathrm{~m}$ outward.

\section{Depth of Proposed Standard Beams}

According to the Greek motorway bridge design guidelines (Greek Ministry of the Environment, Planning and Public Works, 2002), enforced in 2002, the precast beam span to depth ratios should be between 15 and 25. Given that a significant number of the bridges included in the database were designed prior to 2002, there were 9 beam configurations which did not conform to the aforementioned restriction and thus were removed from the dataset to be used in the multilinear regression analysis that follows. The beams corresponding to the remaining 61 configurations were used to carry out two-way correlations between the beam features with the calculation of the correlation coefficient (Table 3).
The results indicate that a statistically significant positive correlation exists between the depth and the length of the beam $(P=0.810)$, as a result of the fact that longer length adds significantly to the beam's dead load and therefore to the required depth. Similarly, statistically significant is the correlation found between the beam's depth and effective width $(P=0.656)$ with the latter being defined as the ratio of the bridge width to the multitude of beams in this dimension. This correlation also makes sense from a structural point of view, as the effective width defines the beam spacing and thus the number of beams in the bridge section; bigger spacing results in less beams with bigger depth so that the load imposed on each beam can be sustained. In addition, a smaller yet significant positive correlation was also found between the beam's depth and the LFW $(P=0.588)$. However, it can also be observed that LFW is highly correlated with $\mathrm{L}(P=0.612)$ and therefore it may not qualify as an independent variable.

Initially, a multiple linear regression analysis was carried out with the aim to estimate the depth, D (dependent variable) as a function of the beam length $(\mathrm{L})$, the effective width $\left(\mathrm{W}_{\text {eff }}\right)$ and the LFW (independent variables). The results (Table 4) showed that for $\mathrm{L}$ and $\mathrm{W}_{\text {eff }}$, the Beta coefficient value was higher enough compared to the standard error, as specified in Field (2013), but this was not the case for the LFW as $0.1<0.287$. Thus, LFW was removed from the analysis and a new regression analysis between D, L, and $\mathrm{W}_{\text {eff }}$ was carried out (Table 5). This resulting linear model (equation 1 ) has a very good fit with $R^{2}=0.792$ denoting that both $\mathrm{L}$ and $\mathrm{W}_{\text {eff }}$ make a significant contribution to the calculation of $D$.

$$
D=(-0.303)+0.047 L+0.248 W_{\text {eff }}
$$

Next, three alternative values, equal to 2, 2.5, and 3, were chosen for the variable of $\mathrm{W}_{\text {eff. }}$. This resulted from the fact that the frequency analysis of the dataset reveals that $31.1 \%$ of the beams have an effective width of less than $2,24.6 \%$ are between 2 and 2.5 and another $29.5 \%$ is between 2.5 and 3 . Given the above and making use of equation 1 for the 15 different beam lengths (L) previously specified between 22 and $43 \mathrm{~m}, 45$ $(3 \times 15)$ corresponding beam depths $(D)$ were calculated and then rounded up to the nearest $0.05 \mathrm{~m}$.

\section{UFW and LFW of Proposed Standard Beams}

The UFW and LFW values selected for the 45 standard beams are 1.40 and $0.75 \mathrm{~m}$ respectively, which are the most frequent respective dimensions encountered in the dataset. The selection of these values was decided after the apparent correlation between $\mathrm{L}$ and LFW was further checked and the resulting regression equation produced a low $R^{2}=0.364$. Therefore, it was concluded that the flange configuration does not seem to have any statistical correlation with other dimensions.

\section{WW of Proposed Standard Beams}

According to the Greek motorway bridge design guidelines (Greek Ministry of the Environment, Planning and Public Works, 2002), the WW should be no less than $0.30 \mathrm{~m}$ for beam depths $<1.0 \mathrm{~m}$ and no less than $0.5 \mathrm{~m}$ for depths $>4.0 \mathrm{~m}$. In between beam depths also have web thickness limits which 
TABLE 3 | Correlations between the dataset's dimensional variables.

\begin{tabular}{|c|c|c|c|c|c|c|c|}
\hline & & $L(\mathrm{~m})$ & $D(\mathrm{~m})$ & UFW (m) & LFW (m) & WW (m) & $W_{\text {eff }}(m)$ \\
\hline \multirow[t]{2}{*}{$L(m)$} & Pearson correlation & 1 & 0.810 & -0.139 & 0.612 & 0.057 & 0.391 \\
\hline & Sig. (two-tailed) & & 0.000 & 0.284 & 0.000 & 0.661 & 0.002 \\
\hline \multirow[t]{2}{*}{$\mathrm{D}(\mathrm{m})$} & Pearson correlation & 0.810 & 1 & -0.071 & 0.588 & -0.149 & 0.656 \\
\hline & Sig. (two-tailed) & 0.000 & & 0.586 & 0.000 & 0.253 & 0.000 \\
\hline \multirow[t]{2}{*}{ UFW (m) } & Pearson correlation & -0.139 & -0.071 & 1 & 0.212 & 0.115 & 0.008 \\
\hline & Sig. (two-tailed) & 0.284 & 0.586 & & 0.100 & 0.376 & 0.953 \\
\hline \multirow[t]{2}{*}{ LFW (m) } & Pearson correlation & 0.612 & 0.588 & 0.212 & 1 & 0.144 & 0.316 \\
\hline & Sig. (two-tailed) & 0.000 & 0.000 & 0.100 & & 0.268 & 0.013 \\
\hline \multirow[t]{2}{*}{ WW (m) } & Pearson correlation & 0.057 & -0.149 & 0.115 & 0.144 & 1 & -0.305 \\
\hline & Sig. (two-tailed) & 0.661 & 0.253 & 0.376 & 0.268 & & 0.017 \\
\hline \multirow[t]{2}{*}{ Effective Width (m) } & Pearson correlation & 0.391 & 0.656 & 0.008 & 0.316 & -0.305 & 1 \\
\hline & Sig. (two-tailed) & 0.002 & 0.000 & 0.953 & 0.013 & 0.017 & \\
\hline
\end{tabular}

TABLE 4 | Regression coefficients for three independent variables.

\begin{tabular}{|c|c|c|c|c|c|c|}
\hline \multirow{2}{*}{\multicolumn{2}{|c|}{ Model }} & \multicolumn{2}{|c|}{$\begin{array}{l}\text { Unstandardized } \\
\text { coefficients }\end{array}$} & \multirow{2}{*}{$\begin{array}{c}\begin{array}{c}\text { Standardized } \\
\text { coefficients }\end{array} \\
\text { Beta }\end{array}$} & \multirow[t]{2}{*}{$t$} & \multirow[t]{2}{*}{ Sig. } \\
\hline & & B & Standard error & & & \\
\hline \multirow[t]{4}{*}{1} & (Constant) & -0.433 & 0.183 & & -2.367 & 0.021 \\
\hline & $\mathrm{L}(\mathrm{m})$ & 0.043 & 0.006 & 0.596 & 7.647 & 0.000 \\
\hline & $W_{\text {eff }}(m)$ & 0.242 & 0.040 & 0.391 & 6.022 & 0.000 \\
\hline & LFW (m) & 0.382 & 0.287 & 0.100 & 1.328 & 0.189 \\
\hline
\end{tabular}

TABLE 5 | Regression coefficients for two independent variables.

\begin{tabular}{|c|c|c|c|c|c|c|}
\hline \multirow{2}{*}{\multicolumn{2}{|c|}{ Model }} & \multicolumn{2}{|c|}{$\begin{array}{l}\text { Unstandardized } \\
\text { coefficients }\end{array}$} & \multirow{2}{*}{$\begin{array}{c}\begin{array}{c}\text { Standardized } \\
\text { coefficients }\end{array} \\
\text { Beta }\end{array}$} & \multirow[b]{2}{*}{$\mathbf{t}$} & \multirow[b]{2}{*}{ Sig. } \\
\hline & & B & Standard Error & & & \\
\hline \multirow{3}{*}{2} & (Constant) & -0.303 & 0.156 & & -1.948 & 0.056 \\
\hline & $\mathrm{L}(\mathrm{m})$ & 0.047 & 0.005 & 0.654 & 10.050 & 0.000 \\
\hline & $W_{\text {eff }}(m)$ & 0.248 & 0.040 & 0.400 & 6.157 & 0.000 \\
\hline
\end{tabular}

can be calculated by linear interpolation. The WW value can be reduced by $0.05 \mathrm{~m}$ for beams produced in factory conditions. Therefore, the WW was calculated for the 45 alternative depth values according to the above guidelines, assuming factory conditions, and then it was rounded up to the nearest $0.02 \mathrm{~m}$.

\section{PROPOSAL FOR THE PROMOTION OF STANDARDIZATION IN ROAD BRIDGES IN GREECE}

Greece is an example of a country long using its public resources less than optimally (Monastiriotis and Psycharis, 2014) as public work contracts often suffer from poor Value for Money (EU Directive, 2014; European Court of Auditors, 2013, 2014a,b). At the same time, the Public Administration's staff lack the necessary knowledge and expertise required to manage investments in infrastructure efficiently and effectively
(Marinelli et al., 2018). In this context, and additionally given the profound adverse impact of the recent 10 -year recession on public investment, the adoption of off-site construction and DfMA practices could greatly benefit the value for money performance of the forthcoming public works in Greece. The sector currently presents an ambitious pipeline of projects including the Northern Motorway in Crete, the central Greece Motorway E65, the extension of the western border motorway 'Olympia Odos' (section from Patras to Pyrgos) and the connection of 'Ionia Odos' Motorway from Ioannina to Albania. In addition, this proposal may also come in useful for other motorway projects planned for the future such as the new Thessaloniki Ring Road, as well as the much needed extensions of 'Attiki Odos' in Athens. Furthermore, the introduction of industrialization in the Greek construction sector would provide the opportunity to geographically spread the benefits of public investment in infrastructure, as the manufacturing process can take place away from the construction site, with more regions potentially benefiting from investment in capital and in skills. However, for this sector transformation to be successfully initiated, legal frameworks and procedures, standards, regulations and policies are of critical importance since these can determine the decisions of designers, contractors and government officials through the entire offsite construction process (Mao et al., 2015).

\section{Proposed Set of Standard Precast Bridge Beams and Implementation Example}

The analysis of section "Rationale for the Determination of Standardized Precast Beams" results in 45 different standard beams as presented in Table 6. These are considered sufficient to cover the vast majority of precast concrete motorway bridges as they have emerged from the analysis of an extensive bridge dataset, covering a variety of designs and geological terrains.

The following easily applied process, resulting from the analysis of Section "Rationale for the Determination of Standardized Precast Beams," is proposed for the selection of the most appropriate standard beam design in a bridge with known total length and width. 
TABLE 6 | Proposed Standardized Extended-I Beams for precast bridges.

\begin{tabular}{|c|c|c|c|c|c|c|}
\hline \multirow[t]{3}{*}{ Length (m) } & \multicolumn{3}{|c|}{$D(m)$} & \multirow[t]{3}{*}{ UFW (m) } & \multirow[t]{3}{*}{ LFW (m) } & \multirow[t]{3}{*}{ WW (m) } \\
\hline & \multicolumn{3}{|c|}{ Effective Width (m) } & & & \\
\hline & 2 & 2.5 & 3 & & & \\
\hline 22.00 & 1.25 & 1.35 & 1.50 & 1.40 & 0.75 & 0.30 \\
\hline 23.50 & 1.30 & 1.40 & 1.55 & 1.40 & 0.75 & 0.30 \\
\hline 25.00 & 1.35 & 1.45 & 1.60 & 1.40 & 0.75 & 0.30 \\
\hline 26.50 & 1.40 & 1.50 & 1.65 & 1.40 & 0.75 & 0.30 \\
\hline 28.00 & 1.45 & 1.55 & 1.70 & 1.40 & 0.75 & 0.30 \\
\hline 29.50 & 1.50 & 1.60 & 1.75 & 1.40 & 0.75 & 0.30 \\
\hline 31.00 & 1.55 & 1.65 & 1.80 & 1.40 & 0.75 & 0.32 \\
\hline 32.50 & 1.60 & 1.70 & 1.80 & 1.40 & 0.75 & 0.32 \\
\hline 34.00 & 1.60 & 1.75 & 1.85 & 1.40 & 0.75 & 0.32 \\
\hline 35.50 & 1.65 & 1.80 & 1.90 & 1.40 & 0.75 & 0.32 \\
\hline 37.00 & 1.70 & 1.85 & 1.95 & 1.40 & 0.75 & 0.32 \\
\hline 38.50 & 1.75 & 1.90 & 2.00 & 1.40 & 0.75 & 0.32 \\
\hline 40.00 & 1.80 & 1.95 & 2.05 & 1.40 & 0.75 & 0.32 \\
\hline 41.50 & 1.85 & 2.00 & 2.10 & 1.40 & 0.75 & 0.34 \\
\hline 43.00 & 1.90 & 2.05 & 2.15 & 1.40 & 0.75 & 0.34 \\
\hline
\end{tabular}

Step 1: Define the distance from pier center to pier center, $\mathrm{d}$, and subtract 0.70 to calculate the maximum allowed beam length $(\mathrm{L}=\mathrm{d}-0.70)$ according to the minimum space required between consecutive beams.

Step 2: Decide the number of beams per cross section so that the $\mathrm{W}_{\text {eff }}$ (Bridge deck width/number of beams) is between 2 and 3

Step 3: Apply the values of $\mathrm{L}$ and $\mathrm{W}_{\mathrm{eff}}$ to equation 1 to estimate the section's depth D

Step 4: Choose the closest beam length and beam depth from the standard beams table.

Step 5: Carry out structural verifications checks and repeat if necessary.

For example, for a 4-span bridge with total length equal to $137.6 \mathrm{~m}$ and width equal to $12.7 \mathrm{~m}$, the pier center to center distance is $d=137.4 / 4=34.4 \mathrm{~m}$. Therefore, the max beam length equals to $L=34.4-0.7=33.7 \mathrm{~m}$. The minimum beam length which could be possibly selected and accommodated on the standard pier head is $L_{\text {min }}=33.7-1.5=32.2 \mathrm{~m}$.

For 6 beams per span, $W_{\text {eff }}=12.7 / 6=2.12$.

The initial depth $D$ is calculated as $-0.303+0.047^{*} 33.7+$ $0.248^{*} 2.12=1.80 \mathrm{~m}$.

After consulting Table 6, the closest beam length is $32.5 \mathrm{~m}>$ Lmin. For the selected length of $32.5 \mathrm{~m}$ and $W_{\text {eff }}=2.12$ the depth is recalculated by equation 1 and equals $D=1.75 \mathrm{~m}$. The value $D=1.80 \mathrm{~m}$ is the next available option in Table 6 and represents a choice on the safe side. The remaining dimensions are $\mathrm{UFW}=1.40 \mathrm{~m}, \mathrm{LFW}=0.75 \mathrm{~m}$ and $\mathrm{WW}=0.32 \mathrm{~m}$.

\section{Other Recommendations \\ Effective Procurement Strategy}

A range of procurement pathways exists for any construction project. However, procurement routes based on the involvement of the contractor in design are the most appropriate ones to achieve the required ease of assembly/buildability level. Such systems are the design and build (DB), the management contracting $(\mathrm{MC})$, the construction management $(\mathrm{CM})$, and the Early Contactor Involvement (ECI) (Finnie et al., 2018), i.e., the procurement system, typically referred to as a twostage procurement process, which allows the contractor to be conditionally appointed before details of what is to be constructed have been fully developed and priced (Marinelli and Antoniou, 2019). Among the abovementioned routes, only the DB can be applied in the Greek public works sector as it is officially part of the EU's relevant legislation (EU Directive, 2014). Under this approach, the owner selects and executes a single contract with a single entity to design and construct the project. In this case, the pre-qualification stage which takes place, could be used as an opportunity for preselection criteria related to off-site construction and collaborative culture attributes to be used. A public project in Norway offers an example of a similar approach, with lean competence being among the procurement criteria; specifically the contractors were asked to describe how they planned to manage the production progress and to organize their logistics in line with lean construction principles (Bygballe et al., 2018).

However, the DB approach also involves disadvantages which may jeopardize the project's value for money, e.g., low competition, increased complexity and restricted use (Marinelli and Antoniou, 2019). Therefore, clients will often use competitive tendering up until the later stages of the design to drive capital cost down (Robinson et al., 2012), i.e., they select the 'traditional' $\mathrm{DBB}$ procurement route. This more often than not is the case with the Greek public works procurement and Egnatia Motorway was no exception: the whole project, initially planned to be constructed under 60 construction contracts according to geographical criteria, was finally constructed via 236 such contracts due to various unforeseen circumstances and numerous design modifications. However, of these 236 contracts, $99 \%$ were procured through a DBB route. Given the popularity of DBB procurement route, it is suggested that the authorities take a 'procure for value' (rather than lowest cost) approach, by associating the project award criteria with social value benefits like environmental and sustainability performance, reduction of waste and health and safety, all of which are significantly enhanced by the use of off-site manufacture. This will give off-site construction solutions a significant lead, regardless the procurement route.

\section{Development of Official Guidelines}

The willingness of the precast industry to invest in, to design and to construct the necessary infrastructure for manufacture of standardized components relies on the push and enforcement of the relevant authorities (Tan et al., 2014). In the absence of official standardization requirements, manufacturers will hesitate to invest in new molds and facilities for any new projects. Therefore, the Greek authorities should develop guidelines outlining standardized elements for all the individual structures encountered in highway projects (e.g., for bridges, tunnels etc.) and make their adoption mandatory in the tender documents, for 
all the relevant design procurement processes. Such an endeavor will require extensive analysis of constructed projects data in cooperation with the respective constructors, so as to enable the tacit construction knowledge which resides in their minds in the form of technical skills, intuitions and insights, to take a concrete form and become widely available for use in future projects. This will alleviate the consequences resulting from the DBB approach's main disadvantage, i.e., the fragmentation due to the separation of design from construction.

Especially for highway projects of significant length, which usually get tendered in separate smaller sections (geographical units), designers can further be guided so as to design the similar structures of the same unit using the same standardized section if possible, so as to enable the constructor to use the same formworks for all the structures of the section. For the case of already existing designs, which have not been constructed yet, it is suggested that the constructors be allowed to change the designs for standardized sections as per the EU Directive's provisions described in Marinelli and Antoniou (2019). This will enable them to potentially avoid the use of additional bespoke equipment. At a later stage, a digital library of BIM based data-rich files of the standard designs should also be developed and made available to both the designers and the contracting authorities, so as to further facilitate and promote the implementation of the standardized elements.

It should be noted that the establishment of the mandatory use of standard beams in the design of precast beam bridges does not preclude their use in the DBB process. On the contrary, as all Greek DBB contracts are based on bills of quantities and official unit rates published by the relevant technical committee, it will allow for a more accurate cost estimate based on specific construction details and market costs that will be known to all in advance, i.e., consultants, contractors and clients.

\section{Suitable Selection of Contracts}

According to Finnie et al. (2018) the optimal procurement strategy to enhance off-site construction should enable not only buildability, but also competitive lump sum pricing in the form of a standard model. The latter can well be achieved by means of the digital library approach previously suggested, as the standardized elements can easily be used as the basis for the preliminary cost estimates required for the use of lump sum price contracts. Such standard forms of construction contract provide familiarity and reliability through being well tried in case law (Kirkham, 2007; Ashworth, 2012) while also presenting high contribution potential to value for money achievement (Antoniou and Aretoulis, 2018). Langford et al. (2003) also confirm that the use of lump sum contracts in roadworks results in significant reduction of the construction cost while requiring less management by the client organization and delivering more harmonious working relationships between the client and the contractor.

\section{Training Opportunities}

Finally, it is of critical importance for any public authority involved in the relevant procurement processes to offer suitable training to its employees, especially at the stage of the standardized elements database development. Training workshops and seminars on the principles of DfMA are necessary to raise their awareness of the benefits that may be derived from standardization and consequently reinforce their commitment. It will also help the engineers to seek for appropriate data from the construction firms and collaborate with them in an efficient manner. Low and Gao (2011) note that such training should be targeted not only at the government officials but also at the industry, and this could be achieved by formally introducing relevant manufacturing course in the curriculum of tertiary institutions.

\section{CONCLUSION}

Prefabrication or off-site manufacture for construction is strongly associated among others with higher productivity and significant cost, time and quality gains, achieved as a result of DfMA, improved constructability and standardization. In this context, concrete operations can particularly benefit from the implementation of manufacturing practices to produce standardized elements such as blocks, pavers, culverts and other structural elements such as slabs and beams. Among the widely used applications of off-site construction in highways is the design and construction of precast concrete beams for bridges, in various profiles and lengths. This research highlighted the efficiency improvement potential typifying the use of standardized designs, making evident how off-site construction including precast concrete applications would be highly beneficial for the improvement of value for money in construction. Furthermore, it investigated the standardization practices in precast bridge beams worldwide and demonstrated the lack of standardization in the design of concrete bridges in Greece. This was evident following the collection and analysis of data from 109 precast concrete bridges comprising 2,284 beams, constructed along the Egnatia Motorway and its connecting axes. The developed database, including information for the dimensions of the respective precast beams (L, D, UFW, LFW, and $\mathrm{WW}$ ), as built, was further used for the implementation of statistical analyses such as multi-linear regression and correlation analysis. These analyses' results, combined with regulatory requirements, enabled the determination of 45 alternative beam configurations which are proposed as standardized elements in the construction of precast concrete bridges. The proposed set of beams includes 15 different lengths in the range between 22 and $43 \mathrm{~m}$ and 3 alternative depths for each length, in order to match the desirable effective width. An implementation example detailing the steps which need to be applied for the determination of the most appropriate standard beam design in a bridge with known total length and width, has also been included. Given, however, that the industrialization of the construction sector in many countries, including Greece, is very low, a more consistent and strategic approach is required for the full efficiency potential of standardized designs to be realized. This includes active governmental promotion of offsite construction and creation of demand for such designs through appropriate public tendering, as well as the simultaneous 
implementation of appropriate regulations and policies. These mainly concern the selection of procurement routes involving the contractor in the design stage as well as contract award criteria favoring the use of off-site construction by emphasizing on total value rather than on minimum cost. The development of official guidelines enforcing the use of standard design elements is also of critical importance. The contribution of suitable project contracts and the need for provision of training to the main stakeholders, are also highlighted. The proposed strategic changes in design and procurement policies are particularly relevant to the Greek public works sector, but other countries with low construction industrialization levels could also benefit from the recommendations provided in this research.

A limitation of the presented proposal lies in the fact that it is based on bridge designs which follow older design standards. Therefore, before applying the proposed standardized beams, a structural check according to the design codes currently in use, should take place. Another limitation of this proposal is that its content has not yet been put in wider consultation with the industry. It would be beneficial to obtain in the future the opinions of Greek practitioners on the reasons behind the lack of standardization in construction and the existence of design or policy constraints that may impede the effective implementation of prefabrication. The discussion of any other difficulty resulting from the specifically proposed standard beam set can also potentially lead to useful amendments. This will also provide valuable insight into further policy changes required to promote standardization and precast concrete

\section{REFERENCES}

Alshawi, M., and Underwood, J. (1996). Improving the constructability of design solutions through an integrated system. J. Eng. Construct. Archit. Manag. 3, 47-67. doi: 10.1108/eb021022

Antoniou, F., and Aretoulis, G. (2018). Comparative analysis of multi criteria decision making methods in choosing highway construction contract type. Intern. J. Manag. Decis. Mak. 17, 1-28.

Antoniou, F., Konstantinidis, D., and Aretoulis, G. (2016a). Analytical formulation for early cost estimation and material consumption of road overpass bridges. Res. J. Appl. Sci. Eng. Technol. 12, 716-725. doi: 10.19026/rjaset.12. 2747

Antoniou, F., Konstantinidis, D., and Aretoulis, G. (2016b). Application of the multi attribute utility theory for the selection of project procurement system for Greek highway projects. Intern. J. Manag. Decis. Mak. 15, 83-112. doi: 10.1504/IJMDM.2016.077761

Antoniou, F., Konstantinidis, D., Aretoulis, G., and Xenides, I. (2017). Preliminary construction cost estimates for motorway underpass bridges. Intern. J. Construct. 18, 321-330. doi: 10.1080/15623599.2017.1358076

Ashworth, A. (2012). Contractual Procedures in the Construction Industry, 6th Edn, Essex: Pearson.

Banks, C., Kotecha, R., Curtis, J., Dee, C., Pitt, N., and Papworth, R. (2018). Enhancing high-rise residential construction through design for manufacture and assembly - a UK case study. Manag. Procur. Law 171, 164-175. doi: 10.1680/jmapl.17.00027

Benaim, R. (2008). The Design of Prestressed Concrete Bridges. Concepts and Principles. London: Taylor \& Francis.

Bjornfot (2008). “An engineering perspective on lean construction theory," in Proceedings for the 16th Annual Conference of the International Group for Lean Construction Theory, Salford.

Bryman, A. (2012). Social Research Methods, 4th Edn, New York, NY: Oxford University Press. solutions in design and construction of highway projects. Further research can also include the development of a prediction model for the material and construction costs of precast beam decks incorporating the proposed standard beams. Furthermore, comparison of the results with other prediction models developed for other bridge types in similar geographical context (e.g., Antoniou et al., 2016a, 2017) can also give additional insights into the extent of the cost efficiency enabled by the use of standard elements.

\section{DATA AVAILABILITY STATEMENT}

The datasets generated for this study will not be made publicly available because of design copyrights and GDPR constraints. Requests to access the datasets should be directed to Egnatia Odos S. A., eoae@egnatia.gr.

\section{AUTHOR CONTRIBUTIONS}

FA conceived the research idea and was responsible for the collection and statistical processing of the dataset. MM devised the research plan and was responsible for the theoretical substantiation of the proposal. FA and MM jointly contributed to the interpretation of the results and the writing of the manuscript. Both authors have made a substantial, direct and intellectual contribution to the work, and approved it for publication.

Burkhart, A., Touran, A., and Qabbani, Z. (1987). Repeating Formwork Greatly Reduces Cost. Boston, MA: The Aberdeen Group.

Bygballe, L. E., Endresen, M., and Falun, S. (2018). The role of formal and informal mechanisms in implementing lean principles in construction projects. Eng. Construct. Architect. Manag. 25, 1322-1338. doi: 10.1108/ECAM-07-20170138

CBDG - Concrete Bridge Development Group (2015). Best Construction Methods for Concrete Bridge Decks - Cost Data: A State-Of-The-Art Report, Technical Guide No. 14. Scottsdale: CBDG.

CIRIA (1999). Standardization And Pre-Assembly: Adding Value To Construction Projects, CIRIA Report No. 176. London: CIRIA.

Construction Industry Development Board of Singapore (1995). Buildable Design Appraisal System, 3rd Edn, Singapore: CIDB.

Dikmen, S. U., and Sonmez, M. (2011). An artificial neural networks model for the estimation of formwork labour. J. Civil Eng. Manag. 17, 340-347. doi: 10.3846/13923730.2011.594154

Duan, L., Chen, K., and Tan, A. (1999). "Prestressed concrete bridges," in Chapter in Bridge Engineering Handbook, eds W.-F. Chen and L. Duan (Boca Raton, FL: CRC Press).

Edum-Fotwe, F. T., Gibb, M., and Benford-Miller, M. (2004). Reconciling construction innovation and standardisation on major projects. Eng. Construct. Architect. Manag. 11, 366-372. doi: 10.1108/09699980410558566

Elhag, H., Glass, J., and Gibb, A. G. F. (2008). Implementing environmental improvements in a manufacturing context: a structured approach for the precast concrete industry. Intern. J. Environ. Technol. Manag. 8, 369-384.

EU Directive (2014). Official Journal of the European Union. Available online at: http://eur-lex.europa.eu/legal-content/EN/TXT/PDF/?uri = CELEX:32014L0024\&from = EN (accessed January 27, 2020).

European Court of Auditors (2013). Are EU Cohesion Policy Funds Well Spent On Roads. Special Report No. 5. Available online at: www.eca.europa.eu/Lists/ECADocuments/SR13_05/SR13_05_EN.PDF (accessed February 22, 2020). 
European Court of Auditors (2014a). Effectiveness of EU-Supported Public Urban Transport Projects. Special Report No. 1. Available online at: www.eca.europa.eu/Lists/ECADocuments/SR14_01/QJAB14001ENC.pdf (accessed February 22, 2020).

European Court of Auditors (2014b). EU-Funded Airport Infrastructures: Poor Value For Money. Special Report No. 21. Available online at: www.eca.europa.eu/Lists/ECADocuments/SR14_21/QJAB14021ENC.pdf (accessed February 22, 2020).

Fellows, R., and Liu, A. (2008). Research Methods for Construction. Chichester: Blackwell Publishing.

Field, A. (2013). Discovering Statistics Using SPSS, 4th Edn, London: Sage Publications.

Finnie, D., Ali, N. A., and Park, K. (2018). Enhancing off-site manufacturing through early contractor involvement (ECI) in New Zealand. Proc. Institut. Civil Eng. Manag. Procur. Law 171, 176-185. doi: 10.1680/jmapl.17.00029

Fischer, M., and Tatum, C. B. (1997). Characteristics of design-relevant constructability knowledge. ASCE J. Construct. Eng. Manag. 123, 253-260. doi: 10.1061/(asce)0733-9364(1997)123:3(253)

Gao, S., Jin, R., and Lu, W. (2020). Design for manufacture and assembly in construction: a review. Build. Res. Inform. 48, 538-550. doi: 10.1080/09613218. 2019.1660608

Gao, S., Low, S. P., and Nair, K. (2018). Design for manufacturing and assembly (DfMA): a preliminary study of factors influencing its adoption in Singapore. Architect. Eng. Design Manag. 14, 440-456. doi: 10.1080/17452007.2018. 1502653

Gerth, R., Boqvist, A., Bjelkemyr, M., and Lindberg, B. (2013). Design for construction: Utilizing production experiences in development. Construct. Manag. Econom. 31, 135-150. doi: 10.1080/01446193.2012.756142

Gibb, A. G. (2001). Standardization and pre-assembly-distinguishing myth from reality using case study research. Construct. Manag. Econom. 19, 307-315. doi: 10.1080/01446190010020435

Gibb, A. G. F. (1999). Off-Site Fabrication: Prefabrication, Pre-Assembly And Modularisation. Hoboken, NJ: John Wiley \& Sons.

Gibb, A. G. F., and Isack, F. (2001). Client drivers for construction projects: implications for standardization. Eng. Construct. Architect. Manag. 8, 46-58. doi: $10.1108 /$ eb021169

Goodier, C., and Gibb, A. (2007). Future opportunities for offsite in the UK. Construct. Manag. Econom. 25, 585-595. doi: 10.1080/01446190601071821

Goodier, C., Gibb, A., Mancini, M., Turck, C., Gjepali, O., and Daniels, E. (2019). Modularisation and offsite in engineering construction: an early decisionsupport tool. Proc. Institut. Civil Eng. Civil Eng. 172, 3-14. doi: 10.1680/jcien. 19.00015

Gray, A., Gaby, P., Brown, G., Kirkcaldie, D., Cato, R., and Sweetman, P. (2003). New Standard Precast Concrete Bridge Beams - Stage 1 - Research \& Identify Proposed Standard Beam Shapes and Spans. Wellington: Transfund Research Centre.

Greek Ministry of the Environment, Planning and Public Works (2002). National Road Works Design Guidelines. Ministerial Decision $\Delta \mathrm{\iota} \alpha / 0 / 7 / 4 / 25-1-02$ $\Upsilon . \Pi \mathrm{X}$.X. $\Delta . \mathrm{E}$.

Huang, R., Chen, J.-J., and Sun, K.-S. (2004). Planning gang formwork operations for building construction using simulations. Autom. Construct. 13, 765-779. doi: 10.1016/j.autcon.2004.05.001

Jarkas, A. M. (2010). Analysis and measurement of buildability factors affecting edge formwork labour productivity. J. Eng. Sci. Technol. Rev. 3, 142-150. doi: $10.25103 /$ jestr.031.24

Jupp, V. (2006). The Sage Dictionary of Social Research Methods. London: Sage Publications LTD.

Kim, M. K., McGovern, S., Belskya, M., Middleton, C., and Brilakis, I. (2016). A suitability analysis of precast components for standardized bridge construction in the United Kingdom. Proc. Eng. 164, 188-195. doi: 10.1016/j.proeng.2016. 11.609

Kirkham, R. (2007). Ferry and Brandon's Cost Planning of Buildings, 8th Edn, Singapore: Blackwell.

Koshy, V. (2005). Action Research for Improving Practice- A Practical Guide, Paul. London: Chapman Publishing.

Laing O'Rourke (2013). The Future of DfMA is The Future Of Construction. Technical Report. Available online at: http://www.laingorourke.com/ /media/ lor/files/lor-engineering-excellence-journal-2013.pdf (accessed February 22, 2020).

Langford, D. A., Kennedy, P., Conlin, J., and Mckenzie, N. (2003). Comparison of construction costs on motorway projects using measure and value and alternative tendering initiative contractual arrangements. Construct. Manag. Econom. 21, 831-840. doi: 10.1080/0144619032000056180

Liu, M. (1997). Fondements et Practiques de la Recherche-Action. Paris: Logiques sociales.

Low, S. P., and Gao, S. (2011). The application of the just-in-time philosophy in the chinese construction industry. J. Construct. Dev. Countries 16, 91-111.

Lu, W., Chen, K., Xue, F., and Pan, W. (2018). Searching for an optimal level of prefabrication in construction: an analytical framework. Cell 201, 236-245. doi: 10.1016/j.jclepro.2018.07.319

Lu, W., Tan, T., Xu, J., Wang, J., Chen, K., Gao, S., et al. (2020). Design for manufacture and assembly (DfMA) in construction: the old and the new. Architect. Eng. Design Manag. (in press). doi: 10.1080/17452007.2020.1768505

Mao, C., Shen, Q., Pan, W., and Ye, K. (2015). Major barriers to off-site construction: the developer's perspective in China. J. Manag. Eng. 31:04014043. doi: 10.1061/(asce)me.1943-5479.0000246

Marinelli, M., and Antoniou, F. (2019). Improving public works' value for money: a new procurement strategy. Intern. J. Manag. Project. Bus. 13, 85-102. doi: 10.1108/ijmpb-04-2018-0084

Marinelli, M., Petroutsatou, K., Fragkakis, N., and Lambropoulos, S. (2018). Rethinking new public infrastructure value for money in recession times: the Greek case. Intern. J. Construct. Manag. 18, 331-342. doi: 10.1080/15623599. 2017.1358131

Martinez, E. H., Alvear, A. M., Tommelein, I. D., and Ballard, G. (2015). "Formwork standardization and production flow: lessons from an affordable housing project in ecuador," in Proceedings of the 23rd Annual Conference of the International Group for Lean Construction, New York, NY

McMullen, M., and Li, C. (2015). Feasibility Study of Developing and Creating a Standardized Subset of Bridge Plans. Report No. CDOT-2015-2015. Denver, CO: Colorado Department of Transport.

Monastiriotis, V., and Psycharis, Y. (2014). Between equity, efficiency and redistribution: an analysis of revealed allocation criteria of regional public investment in Greece. Eur. Urban Reg. Stud. 21, 445-462. doi: 10.1177/ 0969776412455990

Moore, D. (1996). Buildability assessment and the development of an automated design aid for managing the transfer of construction process knowledge. J. Eng. Construct. Architect. Manag. 3, 29-46. doi: 10.1108/eb021021

Nadim, W., and Goulding, J. (2009). Offsite production in the UK: the construction industry and academia. Archit. Eng. Design Manag. 5, 136-152. doi: 10.3763/ aedm.2008.0094

Oberlender, G., and Peurifoy, R. (2011). Formwork for Concrete Structures, 4th Edn, New York, NY: McGraw Hill Professional.

O'Connor, J. T., Rusch, S. E., and Schulz, M. J. (1987). Constructability concepts for engineering and procurement. ASCE J. Construct. Eng. Manag. 113, 235-248. doi: 10.1061/(asce)0733-9364(1987)113:2(235)

O'Leary, Z. (2004). The Essential Guide to Doing Research. London: Sage.

Pan, M., and Pan, W. (2019). Determinants of adoption of robotics in precast concrete production for buildings. J. Manag. Eng. 35:05019007. doi: 10.1061/ (asce)me.1943-5479.0000706

Pan, W., Gibb, A. G. F., and Dainty, A. R. J. (2008). Leading UK housebuilders' utilization of offsite construction methods. Build. Res. Inform. 36, 56-67. doi: 10.1080/09613210701204013

Pan, W., Gibb, A. G. F., and Dainty, A. R. J. (2012). Strategies for integrating the use of off-site production technologies in house building. J. Construct. Eng. Manag. 138, 1331-1340. doi: 10.1061/(asce)co.1943-7862.0000544

Pan, W., and Goodier, C. (2012). House-building business models and off-site construction take-up. J. Architect. Eng. 18, 84-93. doi: 10.1061/(asce)ae.19435568.0000058

Park, M., Yashada, I.-V., Kim, W., and Ham, Y. (2011). Construction policymaking: with an example of Singaporean government's policy to diffuse prefabrication to private sector. KSCE J. Civil Eng. 15, 771-779. doi: 10.1007/s12205-011-1243-4

Pasquire, C. I., and Gibb, A. G. F. (2002). Considerations for assessing the benefits of standardization and pre-assembly in construction. J. Finan. Manag. Prop. Construct. 7, 151-161. 
Perera, H. S. C., Nagarur, N., and Tabucanon, M. T. (1999). Component part standardization: a way to reduce the life-cycle costs of products. Intern. J. Product. Econom. 60-61, 109-116. doi: 10.1016/s0925-5273(98) 00179-0

RIBA (2013). Plan of Work - Designing for Manufacture and Assembly. Newcastle upon Tyne: RIBA Publishing.

Robinson, A., Gibb, A., and Austin, S. (2012). "Standardisation of specification driven buildings with serial and repeat order designs," in Proceedings of the 28th Annual ARCOM Conference, ed. S. D. Smith (Edinburgh: Association of Researchers in Construction Management), 57-66.

Robson, C., and McCartan, K. (2016). Real World Research, 4th Edn, Chichester: John Wiley and Sons.

Rwamamara, R., Simonsson, P., and Ojanen, J. (2010). Advantages of industrialized methods used in small bridge construction. Proc. IGLC 18, 569-579.

Shapira, A. (1999). Contemporary trends in formwork standards - a case of study. ASCE J. Construct. Eng. Manag. 125, 69-75. doi: 10.1061/(asce)07339364(1999)125:2(69)

Tan, G. E., Ong, T. B., Ong, C. Y., and Choong, K. K. (2014). Development and standardization of new precast concrete open spandrel arch bridge system, 37th IABSE symposium. Economics 102, 799-806. doi: 10.2749/ 222137814814066960

Tan, T., Lu, W., Tan, G., Xue, F., Chen, K., Xu, J., et al. (2020). Constructionoriented design for manufacture and assembly (DfMA) guidelines. J. Construct. Eng. Manag. (in press).

Tawiah, P. A., and Russell, A. D. (2008). Assessing infrastructure project innovation potential as a function of procurement mode. J. Manag. Eng. 24:3.

Taylor, M. D. (2010). A definition and valuation of the UK offsite construction sector. Construct. Manag. Econ. 28, 885-896. doi: 10.1080/01446193.2010. 480976
Taylor, S. J., Bogdan, R., and DeVault, M. L. (2016). Introduction to Qualitative Research Methods: A Guidebook and Resource. Hoboken, NJ: Wiley.

Tegos, N., and Aretoulis, G. (2018). Proposal for an effective decision support system for the pre-selection of the type of concrete highway bridges. Intern. J. Multicrit. Decisi. Mak. 8, 38-59.

UK Government (2018a). Proposal For A New Approach To Building: Call For Evidence, Infrastructure and Projects Authority. Available online at: https://assets.publishing.service.gov.uk/government/uploads/system/uploads/ attachment_data/file/758996/CCS207_CCS1118988908-001_New_Approach_ to_Building_WEB_ACCESSIBLE.pdf (accessed February 22, 2020).

UK Government (2018b). Response to House of Lords Science and Technology Committee Report. Department for Business, Energy and Industrial Strategy. Available online at: https://publications.parliament.uk/pa/ld201719/ldselect/ ldsctech/169/16902.htm (accessed February 22, 2020).

UK Parliament (2018). Off-Site Manufacture for Construction: Building for change. House of Lords, Science and Technology Select Committee. Paper 169. Available online at: https://www.parliament.uk/off-site-manufactureconstruction (accessed February 22, 2020).

Conflict of Interest: The authors declare that the research was conducted in the absence of any commercial or financial relationships that could be construed as a potential conflict of interest.

Copyright (c) 2020 Antoniou and Marinelli. This is an open-access article distributed under the terms of the Creative Commons Attribution License (CC BY). The use, distribution or reproduction in other forums is permitted, provided the original author(s) and the copyright owner(s) are credited and that the original publication in this journal is cited, in accordance with accepted academic practice. No use, distribution or reproduction is permitted which does not comply with these terms. 